\title{
1 A hybrid thermal management system for 2 lithium ion batteries combining phase 3 change materials with forced-air cooling
}

4 Ziye Ling, Fangxian Wang, Xiaoming Fang, Xuenong Gao, Zhengguo Zhang*

5 Key Laboratory of Enhanced Heat Transfer and Energy Conservation, the Ministry of

6 Education, School of Chemistry and Chemical Engineering, South China University

7 of Technology, Guangzhou, 510640, China

8

$9{ }^{*}$ Corresponding author, Tel: 8620 87112845, Fax: 8620 87113870, Email:

10 cezhang@scut.edu.cn 
12 Abstract

13 Passive thermal management systems using phase change materials (PCMs)

14 provides an effective solution to the overheating of lithium ion batteries. But this

15 study shows heat accumulation in PCMs caused by the inefficient cooling of air

16 natural convection leads to thermal management system failures: The temperature in a

17 battery pack operating continuously outranges the safety limit of $60{ }^{\circ} \mathrm{C}$ after two

18 cycles with discharge rate of $1.5 \mathrm{C}$ and $2 \mathrm{C}$. Here a hybrid system that integrates

19 PCMs with forced air convection is presented. This combined system successfully

20 prevents heat accumulation and maintains the maximum temperature under $50{ }^{\circ} \mathrm{C}$ in

21 all cycles, even with $7{ }^{\circ} \mathrm{C}$ rise in the ambient temperature. Study on airspeed effects

22 reveals that thermo-physical properties of PCMs dictate the maximum temperature

23 rise and temperature uniformity in the battery pack, while forced air convection plays

24 a critical role in recovering thermal energy storage capacity of PCMs. A numerical

25 study is also carried out and validated with experiment data, which gives theoretic

26 insights on thermo-physical changes in this hybrid battery thermal management

27 system.

28 Key words: phase change material; forced air convection; thermal management; 
29 Li-ion battery; passive cooling; hybrid system. 


\section{1. Introduction}

32 Li-ion batteries are considered as excellent power sources for hybrid or electric

33 vehicles (HEVs/EVs) due to high energy and power density [1]. However, the

34 remarkable deterioration in the performance of Li-ion batteries at elevated

35 temperatures is hampering their practice applications [2-4]. It has been reported that

36 the optimum operating temperatures for Li-ion batteries should range from 20 to 50

$37{ }^{\circ} \mathrm{C}$, and the maximum temperature difference in a battery pack should be kept within 5

$38{ }^{\circ} \mathrm{C}$ [5]. Consequently, efficient thermal management systems are highly needed for

39 Li-ion batteries to remove the massive amounts of heat generated in the

40 charge/discharge process.

41 Forced air convection is a routine solution to thermal management of electronic

42 components. However, forced air convection brings about nonuniform temperature

43 distribution in a battery pack, leading to different degrading rates for each cell $[6,7]$;

44 As a result, the cycle life of the whole pack would be shortened. Although optimizing

45 the flow ducts for air can improve the temperature uniformity, system complexity is

46 also increased [8-11].

47 Recently, passive thermal management system using phase change materials 
(PCMs) have been developed as an alternative to active cooling. Taking advantage of

49 high latent heat, PCMs can absorb the massive amounts of heat generated by Li-ion

50 batteries and keep the temperatures of the batteries within the melting range of the

51 PCMs $[12,13]$, thereby reducing both the maximum temperature and the temperature

52 difference in the battery pack [14-16]. Furthermore, the performance of the passive

53 thermal management systems can be improved via the enhancement in the thermal

54 conductivity of the PCMs by adding some thermal conductive materials like metal

55 foams [17, 18], graphene [19], or expanded graphite (EG) [20-23]. Mills et al. [20]

56 reported that PCMs decreased the capacity loss rate of Li-ion batteries by more than

$5750 \%$.

58 In spite of the high efficiency, PCMs can only absorb heat passively. Running out

59 of the available latent heat under extreme conditions - such as high heat density

60 during the high-current charge or discharge, or high ambient temperature - may cause

61 the thermal management systems [24]. Even under mild conditions (ambient

62 temperature $<30{ }^{\circ} \mathrm{C}$ and discharge rate $<2 \mathrm{C}$ ), lack of external cooling may also lead

63 to thermal management system failures. A typical charge-discharge protocol for

64 batteries includes three steps: (1) constant-current charging; (2) constant-voltage 
65 charging; (3) constant-current discharging. In continuous operations, most heat is

66 generated by batteries during discharging (Step 3), which is absorbed by PCMs. The

67 heat stored in PCMs can only be dissipated to the ambient during charging (Step 1

68 and Step 2). If natural convection is not sufficient to cool batteries and PCMs down

69 before the next discharge starts, accumulated consumption of latent heat will result in

70 uncontrollable battery temperature rise. Therefore, passive thermal management

71 systems using PCMs are needed to combine with more efficient active cooling to

72 avoid potential failures and improve its reliability. However, few attention has been

73 paid on hybrid active-passive thermal management systems by now, except Hassan

74 introduced forced air convection to improve the performance of a passive thermal

75 management system at high ambient temperatures [25].

76 In the current work, a novel thermal management system that integrates the PCM

77 and forced air convection is presented for a 5S4P Li-ion battery pack that charges and

78 discharges continuously without rest. Its thermal management performance is

79 compared with the passive thermal management system using paraffin/EG composite.

80 This hybrid system is supposed to boost the reliability of PCM-based thermal

81 management system without sacrificing its simple structure. Besides the experimental 
82 investigation, a numerical study based on the combination of thermal models for

83 batteries [26-28] and the enthalpy-based models for PCMs [29] is also carried out and

84 validated with the experiment data, which gives theoretic insights into

85 thermo-physical changes in this hybrid thermal management systems.

\section{2. Experimental Section}

$87 \quad$ 2.1. Battery pack

88 Twenty 18650 Li-ion batteries (Samsung, ICR18650-26FM, 2.6Ah) were

89 connected in the way of 5S4P (five cells in series and four cells in parallel).

90 Specifications of this battery module are listed in Table 1. The spacing between

91 centers of two neighboring cells was $30 \mathrm{~mm}$. As shown in Figure. 1(a), six K-type

92 thermocouples with error less than $0.5{ }^{\circ} \mathrm{C}$ were attached to the battery surface (marked

93 in green), to monitor the temperature evolution of batteries. Thermal management

94 performance is judged by two indices: (1) the maximum temperature $\mathrm{T}_{\max }$ and (2) the

95 maximum temperature difference $\Delta \mathrm{T}$ in this pack. In any cases, lower $\mathrm{T}_{\max }$ and $\Delta \mathrm{T}$ are

96 desirable.

97 The battery pack was charged and discharged by a battery cycler CT2001D,

98 manufactured by Wuhan LAND electronics Co., Ltd, China, current and voltage 
99 accuracy of which were $\pm 0.1 \%$. The charge process of the battery module was the

100 same, which first charge the pack in galvanostatic mode at $1 \mathrm{C}$ rate with a voltage

101 cut-off limit of $4.25 \mathrm{~V}$ per cell followed by a potentiostatic mode until the current

102 drops to $50 \mathrm{~mA}$ per cell. The fully charged battery module was then discharged at

103 constant C-rates - 1C, $1.5 \mathrm{C}$ or $2 \mathrm{C}$ - with a voltage cut-off limit of $2.75 \mathrm{~V}$ per cell. The

104 charge-discharge cycle went on for five times, but would be manually stopped to

105 prevent damages to batteries if the maximum temperature of battery exceeded $60{ }^{\circ} \mathrm{C}$.

106 2.2. Thermal management systems

107 Battery performance was tested under two different thermal management

108 systems: (1) completely passive thermal management system; (2) hybrid thermal

109 management system that combined PCMs with force air convection.

110 In the passive thermal management system, batteries were surrounded by

111 RT44HC/EG composite PCMs. RT44HC (purchased from Ruhr Energy Technology

112 Co., Ltd, Hangzhou, China) was chosen as the basic PCM, due to its proper melting

113 point and high specific phase change enthalpy. RT44HC/EG composites were

114 prepared in the same way as mentioned in [30]. Thermo-physical properties of

115 RT44HC/EG composite are listed in Table 2. Passive thermal management was tested 
116 at the ambient temperature around $25{ }^{\circ} \mathrm{C}$.

117 In the system combining PCM with forced air convection, the battery module

118 that had inserted into RT44HC/EG composites was put into an air tunnel with a

119 rectangular cross section, whose area was $200 \times 200 \mathrm{~mm}^{2}$. The full structure also

120 included: a $500 \mathrm{~mm}$ long contraction with the inlet cross section area of $400 \times 400$

$121 \mathrm{~mm}^{2}$; two valves that controlled air flow rate; and an exhaust fan that drew in air, as

122 shown in Figure 1(b). Before flow through the battery module, airspeed was measured

123 by an anemometer (KA33, provided by KANOMAX) with an accuracy of $\pm 0.1 \mathrm{~m} / \mathrm{s}$.

124 The inlet temperature of air ranged from $30-34{ }^{\circ} \mathrm{C}$. The airspeed was firstly fixed to 5

$125 \mathrm{~m} \mathrm{~s}^{-1}$, but then set to $3 \mathrm{~m} \mathrm{~s}^{-1}, 1 \mathrm{~m} \mathrm{~s}^{-1}$ to further study the effect of airspeed on thermal

126 management performance.

127 In this study, charge efficiency reached over $95 \%$ and discharge efficiency

128 ranged from $80 \%$ to $95 \%$, depending on discharge rates. Difference of

129 charge/discharge efficiency in two different thermal management systems was less

130 than 5\% unless it was manually stopped, because thermal management systems has a

131 small impact on battery cycle performance in only five cycles. We focus on battery

132 thermal characteristics in different thermal management systems, rather than its 
133 electrochemical performance.

\section{3. Mathematical model}

\section{3.1. Battery model}

136 Two models can describe the heat generation in batteries: 1) First-principle

137 models that track the progress of electrochemical reactions, part of which comprises

138 the heat generation term [31-34]; 2) Lump-capacitance model that focuses on battery

139 thermal behaviors [8, 26-28].

140 The lump-capacitance model is used in this work, because of its smaller

141 computational cost. Lump-capacitance model considers physical properties in the

142 battery cell homogeneous, and calculates heat generation rate with the measured the

143 current-voltage characteristics of batteries.

144 The energy conservation equation in a battery cell is specified as

$$
\rho_{\mathrm{b}} \mathrm{c}_{\mathrm{p}, \mathrm{b}} \frac{\partial T}{\partial t}=\mathrm{k}_{\mathrm{b}} \nabla^{2} T+q
$$

145 Where $\rho_{\mathrm{b}}, \mathrm{c}_{\mathrm{p}, \mathrm{b}}$ and $\mathrm{k}_{\mathrm{b}}$ represent density, specific heat and thermal conductivity of

146 battery, which is listed in Table 2. $\mathrm{T}$ and t represent the local temperature and time, $\mathrm{q}$

147 is the battery heat generation rate per unit volume, which is approximated by the sum

148 of the irreversible Joule heat $\mathrm{q}_{\text {irr }}$ and reversible entropic heat $\mathrm{q}_{\mathrm{rev}}$ 
150 determined by the product of current I and the difference between terminal voltage $U$

151 and equilibrium voltage $\mathrm{E}$ :

$$
q_{i r r}=\frac{\mathrm{I}(\mathrm{U}-\mathrm{E})}{\mathrm{V}}
$$

152 where $\mathrm{V}$ is the volume of each battery cell. $\mathrm{U}$ for every single cell was recorded

153 during charge and discharge cycles by the battery cycler. E was approximated by the

154 voltage during the charge and discharge of one battery at a low C-rate: $0.05 \mathrm{C}$.

155 Although the current was small enough, the voltage during a charge differentiated

156 from that in discharge. Therefore, correlations between E and DOD were provided for

157 charge and discharge separately:

$158 \mathrm{E}=-5.50 \times \mathrm{DOD}^{4}+8.65 \times \mathrm{DOD}^{3}-3.69 \times \mathrm{DOD}^{2}-0.45 \times \mathrm{DOD}+4.12,(3-1) \quad$ for discharge

$\mathrm{E}=-28.67 \times \mathrm{DOD}^{6}+73.93 \times \mathrm{DOD}^{5}-73.96 \times \mathrm{DOD}^{4}+35.05 \times \mathrm{DOD}^{3}-6.95 \times \mathrm{DOD}^{2}-$

$160 \quad 0.50 \times \mathrm{DOD}^{4}+4.23$

(3-2) for charge

161 The reversible heat represents the entropic loss $\Delta \mathrm{S}$ and is given as

$$
q_{r e v}=-\frac{T \Delta S}{\mathrm{~V}}(4)
$$

162 The entropy change was an function of DOD and I, based on the data in [27], a

163 correlation is given by: 
165 In which $\mathrm{F}$ is the Faraday constant, $96485.3 \mathrm{C} \mathrm{mol}^{-1}$.

\section{3.2. PCM model}

$$
\begin{aligned}
& \rho_{P C M} \frac{\partial H}{\partial t}=k_{P C M} \nabla^{2} T \\
& \mathrm{H}=\mathrm{h}+\Delta \mathrm{H} \\
& \mathrm{h}=\int_{T_{0}}^{T} c_{p, P C M} d T \\
& \Delta \mathrm{H}=\beta \gamma \quad \\
& \beta= \begin{cases}0 & T<T_{m} \\
1 & T>T_{m}\end{cases}
\end{aligned}
$$

171 enthalpy of PCM, h- sensible heat of PCM, $\triangle \mathrm{H}$ - enthalpy of melted PCM, $\beta-$

172 liquid fraction of melted PCM, $\gamma$ - specific phase change enthalpy.

\section{3.3. Initial conditions and boundary conditions}

174 The initial state is specified as:

$175 \quad \mathrm{t}=0$ 
177 Boundary condition at the interface between battery and PCM relies on the

178 energy conservation:

$$
-k_{b} \frac{\partial \mathrm{T}}{\partial n}=-k_{P C M} \frac{\partial T}{\partial n}
$$

179

$180 \frac{\partial T}{\partial n}$ represents temperature gradient.

181 The contact surface between PCM and the aluminum container shares similar

182 boundary condition:

$$
-k_{P C M} \frac{\partial \mathrm{T}}{\partial n}=-k_{A l} \frac{\partial T}{\partial n}
$$

183 The energy equation at the boundary between heat sink and the ambient is given

184 by:

$$
-k_{A l} \frac{\partial \mathrm{T}}{\partial n}=\alpha\left(\mathrm{T}-T_{a m b}\right)
$$

185 Measuring the convective heat transfer coefficient $\alpha$ is a tough task, so we

186 undertook a preliminary CFD study with commercial software Fluent 6.3 to determine

$187 \alpha$ on average. Battery pack was simplified to six walls with a constant temperature of

$18842{ }^{\circ} \mathrm{C}$ (phase change temperature), over which air flowed at different rates, as shown

189 in Figure. 2. Heat transfer between the six surfaces and air was simulated, and heat 
191 After assigning initial conditions and boundary conditions, battery model and

192 PCM model were solved simultaneously by Fluent 6.3.

\section{4. Results and Discussion}

194 4.1. Comparison on Performance of Passive and Active

\section{Thermal Management Systems}

196 Figure 3 (a) compares the maximum temperature $\left(\mathrm{T}_{\max }\right)$ history in the battery

197 pack equipped with two different thermal management systems, discharging at

198 1C-rate. Both the completely passive thermal management system (black lines) and

199 the enhanced system that combines PCM with forced air convection (red lines)

200 successfully kept battery temperature under $45^{\circ} \mathrm{C}$ in all five cycles. Peak temperature

201 in each cycle was similar between two thermal management systems, but $T_{\max }$ at the

202 end of a charge in the combined system was lower than the completely passive

203 system - even though the ambient temperature was nearly $7{ }^{\circ} \mathrm{C}$ higher.

204 With higher discharge rates such as $1.5 \mathrm{C}$ and $2 \mathrm{C}$, the completely passive

205 systems only succeeded in controlling battery temperature under $45^{\circ} \mathrm{C}$ in the first two

206 cycles, but failed at the third discharge: $\mathrm{T}_{\max }$ exceeded $60{ }^{\circ} \mathrm{C}$, as shown in upper black 
207 lines Figure. 3(b) and Figure. 3(c).

208 The poor heat transfer rate between PCMs and the ambient should be responsible

209 for the failure of passive thermal management system. When discharging at small

210 currents, small amounts of heat produced by batteries are stored in PCMs primarily as

211 sensible heat, which can be easily dissipated to the ambient environment via the low

212 efficient air natural convection. However, with high-current discharge, much more

213 heat is generated and stored in PCM primarily as latent heat. Although at lower

214 ambient temperature, the inefficient air natural convection is unable to fully release

215 the latent heat before next discharge starts, which: 1) reduces heat storage capacity; 2)

216 increases the initial temperature for next discharge. After several discharges, the

217 shrinked thermal energy storage capacity fails to deal with the high heat flux from

218 batteries - latent heat is run out in very short time and battery temperature rises

219 beyond the safety limit.

220 The hybrid system provides a more reliable thermal management performance.

221 Auxiliary forced air convection cools PCM down below its phase change temperature

222 during the charge, which prevents heat accumulation. Full recovery of latent heat

223 helps maximize the thermal energy storage capacity of PCM and keep $\mathrm{T}_{\max }$ under 46 
$224{ }^{\circ} \mathrm{C}$ in all cycles, as show in red lines in Figure. 3(b) and Figure. 3(c). Forced air

225 convection lowers the battery temperature and accelerates the latent heat release,

226 preventing the failure of the PCM-based passive thermal management system.

227 Temperature distribution in both the completely passive or combined thermal

228 management system remains uniform, thanks to the high thermal conductivity and

229 heat capacity of RT44HC/EG. In all cycles discharging at any rates, the average

230 maximum temperature difference in the module is kept below $3{ }^{\circ} \mathrm{C}$, as show in Figure

2314.

\section{4.2. Airspeed effect}

233 Figure. 5 compares $\mathrm{T}_{\max }$ histories in the hybrid systems with different airspeeds,

234 showing airspeed higher than $3 \mathrm{~m} \mathrm{~s}^{-1}$ is sufficient to prevent heat accumulation to keep

235 battery temperature within safety range throughout all cycles.

236 However, the maximum temperature in the first cycle was kept below $46{ }^{\circ} \mathrm{C}$ -

237 close to the phase change temperature of RT44HC - in both the completely passive

238 system and hybrid system with airspeed of $5 \mathrm{~m} \mathrm{~s}^{-1}$.The PCM with the maximum

239 thermal energy storage capacity dominates the maximum battery temperature rise.

240 Controlling battery temperature within the optimum range requires PCMs with proper 
241 phase change temperature and sufficient amount of available latent heat.

242 In addition, the average temperature difference in the battery pack is also

243 independent of airspeeds, as shown in Figure.6. Great heat capacity and thermal

244 conductivity of the PCM/EG composite dictates a uniform temperature distribution.

245 Thermo-physical properties including the phase change temperature,

246 sensible/latent heat capacity and thermal conductivity play an important role in

247 PCM-based thermal management systems. Active cooling plays a more important role

248 in cooling PCM down to unleash PCM's potential in thermal energy storage.

\section{4.3. Model validation}

250 Temperature history of Cell 2 and Cell 5 obtained from simulation is compared

251 with experiment data, shown in Figure. 7(a d). In the system cooled by air natural

252 convection, numerical result matches well with experiment well.

253 In the system cooled by forced air convection, numerical model underpredicts

254 battery temperature. Neglecting thermal resistance between battery and PCMs or

255 prediction errors of convective heat transfer rate in our preliminary CFD study may

256 contributes to these deviation. Simulation also reports a slower temperature drop near

$25742{ }^{\circ} \mathrm{C}$ but faster near $37^{\circ} \mathrm{C}$. Due to the limit of Fluent solver, we assumed that PCM 
258 only had one endothermic peak and one exothermic peak during phase change. But

259 the composite PCM actually has two endothermic peaks and two exothermic peaks, as

260 shown in the DSC curve in Fig. 8. One-peak assumption makes sense in the melting

261 process, because of the narrow difference between two peaks $\left(<2{ }^{\circ} \mathrm{C}\right)$. But as the the

262 second exothermic peak temperature $\left(36.3{ }^{\circ} \mathrm{C}\right)$ is much lower than the first peak

263 (43. $\left.3^{\circ} \mathrm{C}\right)$. This assumption to put two peaks into one causes two problems: (1)

264 increases the latent heat of first exothermic peak, which slows down the temperature

265 drop at $42{ }^{\circ} \mathrm{C} ; 2$ ) neglect the second phase change, which accelerates the temperature

266 drop at $37{ }^{\circ} \mathrm{C}$ - which explains the discrepancy between model and experiment. But

267 overall, numerical results match experiment data well: the average temperature

268 difference between numerical model and experiment is less than $2.3{ }^{\circ} \mathrm{C}$.

269 With the help of numerical model, we can give an insight of the impact of heat

270 accumulation. Figure 9 demonstrates melting fraction of PCMs along with time, in

271 systems with different airspeed. In the system cooled by air natural convection and

272 forced convection with airspeed $\leqslant 1 \mathrm{~m} \mathrm{~s}^{-1}$, melting fraction rises from $50 \%$ and $35 \%$

273 at the end of first cycle, to $90 \%$ and $78 \%$ at the end of fourth cycle, which is a sign of

274 ongoing reduction of latent heat. For systems cooled by strong convection (air 
275 speed $>=3 \mathrm{~m} \mathrm{~s}^{-1}$ ), melting fraction at the end of each cycle drops down to zero due to

276 the efficient heat transfer between heat sink and the ambient. A full recovery of

277 thermal energy storage capacity helps control battery temperature under safety limit.

\section{5. Conclusions}

279 This study aims at raising attentions on potential failures of thermal management

280 systems using PCMs for Li-ion batteries under stressful operations and the

281 significance of effective external cooling for PCMs.

282 We find that heat accumulation in PCMs caused by the inefficient natural

283 convection of air will lead to the final failure of the passive thermal management

284 system. Although the PCM-based thermal management system effectively maintains

285 battery temperature within safety range in a single charge-discharge cycle, the

286 maximum temperature in the 5S4P battery pack exceeds the safety limit of $60{ }^{\circ} \mathrm{C}$ after

287 two cycles, with charge rate of $1 \mathrm{C}$ and discharge rate of $1.5 \mathrm{C} / 2 \mathrm{C}$, at room temperature

288 of $25^{\circ} \mathrm{C}$.

289 Integrating PCMs with the more efficient active cooling improves the reliability

290 of passive thermal management system. The hybrid system presented in this paper

291 that combines forced air convection successfully controlled the maximum temperature 
292 of the battery pack below $50{ }^{\circ} \mathrm{C}$ in cycles at any rates lower than $2 \mathrm{C}$, even with a $7{ }^{\circ} \mathrm{C}$

293 increase in ambient temperature.

294 The introduction of forced air convection will not affect the uniform temperature

295 distribution provided by PCMs. The maximum temperature difference in the hybrid

296 thermal management system was less than $3{ }^{\circ} \mathrm{C}$.

297 Study on airspeed effects shows the maximum temperature rise and the

298 maximum temperature difference in the battery pack is independent on air speed only

299 if PCM has full thermal energy storage capacity. Therefore, PCMs and forced air

300 convection are considered to play different roles in battery thermal management-

301 PCMs control the maximum temperature and the maximum temperature difference in

302 battery pack, while forced air convection cools PCMs down in intervals between two

303 discharges, which helps recover the latent heat of PCMs.

304 Numerical model shows reasonable agreement with experiment, with average

305 temperature deviation less than $2.3{ }^{\circ} \mathrm{C}$. It is easy to observe from numerical results

306 that melting fraction of PCMs at the end of each cycle keeps rising in the completely

307 passive thermal management system, but remains zero in the hybrid thermal

308 management system, which helps explain the heat accumulation in PCMs. 
310 has a simple structure, high efficiency and reliability. Our further studies will focus on

311 taking advantage of the higher cooling efficiency of active cooling to cut the 312 excessive weight of PCMs.

\section{Acknowledgement}

314 This work was supported by the Industry-University-Research Cooperation

315 Project of Guangdong Province and Chinese Education Ministry (2012B091100142),

316 the Joint Project of JST-MOST (2013DFG60080) and the Fundamental Research

317 Funds for the Central Universities (2014ZM0054)

318 References

319 [1] Rao Z, Wang S. A review of power battery thermal energy management.

320 Renewable and Sustainable Energy Reviews. 2011;15:4554-71.

321 [2] Ramadass P, Haran B, White R, Popov BN. Capacity fade of Sony 18650

322 cells cycled at elevated temperatures: Part I. Cycling performance. Journal of Power

323 Sources. 2002;112:606-13.

324 [3] Ramadass P, Haran B, White R, Popov BN. Capacity fade of Sony 18650

325 cells cycled at elevated temperatures: Part II. Capacity fade analysis. Journal of power 
sources. 2002;112:614-20.

327

[4] Wang Q, Ping P, Zhao X, Chu G, Sun J, Chen C. Thermal runaway caused 328

fire and explosion of lithium ion battery. Journal of Power Sources. 2012;208:210-24.

Chemical Thermodynamics. 2012;46:80-5.

331

[6] Fan L, Khodadadi JM, Pesaran AA. A parametric study on thermal

332

management of an air-cooled lithium-ion battery module for plug-in hybrid electric

333 vehicles. Journal of Power Sources. 2013;238:301-12.

334

[7] Sabbah R, Kizilel R, Selman JR, Al-Hallaj S. Active (air-cooled) vs. passive

(phase change material) thermal management of high power lithium-ion packs:

336 Limitation of temperature rise and uniformity of temperature distribution. Journal of

337 Power Sources. 2008;182:630-8.

338 [8] Mahamud R, Park C. Reciprocating air flow for Li-ion battery thermal

339 management to improve temperature uniformity. Journal of Power Sources.

$340 \quad 2011 ; 196: 5685-96$.

341 [9] Park S, Jung D. Battery cell arrangement and heat transfer fluid effects on the

342 parasitic power consumption and the cell temperature distribution in a hybrid electric 
343 vehicle. Journal of Power Sources. 2013;227:191-8.

344 [10] Fathabadi H. A novel design including cooling media for Lithium-ion

345 batteries pack used in hybrid and electric vehicles. Journal of Power Sources.

$346 \quad 2014 ; 245: 495-500$.

347 [11] Xu XM, He R. Research on the heat dissipation performance of battery pack

348 based on forced air cooling. Journal of Power Sources. 2013;240:33-41.

349 [12] Khateeb SA, Farid MM, Selman JR, Al-Hallaj S. Design and simulation of a

350 lithium-ion battery with a phase change material thermal management system for an

351 electric scooter. Journal of Power Sources. 2004;128:292-307.

352 [13] Al-Hallaj S, Selman JR. Thermal modeling of secondary lithium batteries

353 for electric vehicle/hybrid electric vehicle applications. Journal of Power Sources.

$354 \quad 2002 ; 110: 341-8$.

355 [14] Somasundaram K, Birgersson E, Mujumdar AS. Thermal-electrochemical

356 model for passive thermal management of a spiral-wound lithium-ion battery. Journal

357 of Power Sources. 2012;203:84-96.

358 [15] Duan X, Naterer GF. Heat transfer in phase change materials for thermal

359 management of electric vehicle battery modules. International Journal of Heat and 
Mass Transfer. 2010;53:5176-82.

361 [16] Javani N, Dincer I, Naterer GF, Yilbas BS. Heat transfer and thermal

362 management with PCMs in a Li-ion battery cell for electric vehicles. International

363 Journal of Heat and Mass Transfer. 2014;72:690-703.

364 [17] Khateeb SA, Amiruddin S, Farid M, Selman JR, Al-Hallaj S. Thermal

365 management of Li-ion battery with phase change material for electric scooters:

366 experimental validation. Journal of Power Sources. 2005;142:345-53.

367 [18] Li WQ, Qu ZG, He YL, Tao YB. Experimental study of a passive thermal 368 management system for high-powered lithium ion batteries using porous metal foam 369 saturated with phase change materials. Journal of Power Sources. 2014;255:9-15.

370 [19] Goli P, Legedza S, Dhar A, Salgado R, Renteria J, Balandin AA. 371 Graphene-enhanced hybrid phase change materials for thermal management of Li-ion 372 batteries. Journal of Power Sources. 2014;248:37-43.

373 [20] Mills A, Farid M, Selman JR, Al-Hallaj S. Thermal conductivity 374 enhancement of phase change materials using a graphite matrix. Applied Thermal 375 Engineering. 2006;26:1652-61.

376 [21] Rao Z, Wang S, Zhang G. Simulation and experiment of thermal energy 
377 management with phase change material for ageing LiFePO4 power battery. Energy

378 Conversion and Management. 2011;52:3408-14.

379 [22] Zhang ZG, Fang XM. Study on paraffin/expanded graphite composite phase

380 change thermal energy storage material. Energy Conversion and Management.

$381 \quad 2006 ; 47: 303-10$.

382 [23] Kizilel R, Sabbah R, Selman JR, Al-Hallaj S. An alternative cooling system

383 to enhance the safety of Li-ion battery packs. Journal of Power Sources.

$384 \quad 2009 ; 194: 1105-12$.

385 [24] Kizilel R, Lateef A, Sabbah R, Farid MM, Selman JR, Al-Hallaj S. Passive

386 control of temperature excursion and uniformity in high-energy Li-ion battery packs

387 at high current and ambient temperature. Journal of Power Sources. 2008;183:370-5.

388 [25] Hassan F. High thermal performance lithium-ion battery pack including

389 hybrid active-passive thermal management system for using in hybrid/electric

$390 \quad$ vehicles. Energy. 2014;70:529-38.

391 [26] Huang Q, Yan M, Jiang Z. Thermal study on single electrodes in lithium-ion

392 battery. Journal of power sources. 2006;156:541-6.

393 [27] Onda K, Ohshima T, Nakayama M, Fukuda K, Araki T. Thermal behavior of 
394 small lithium-ion battery during rapid charge and discharge cycles. Journal of Power

395 Sources. 2006; 158:535-42.

396 [28] Sato N. Thermal behavior analysis of lithium-ion batteries for electric and

397 hybrid vehicles. Journal of Power Sources. 2001;99:70-7.

398 [29] Al-abidi AA, Bin Mat S, Sopian K, Sulaiman MY, Mohammed AT. CFD

399 applications for latent heat thermal energy storage: a review. Renewable and

$400 \quad$ Sustainable Energy Reviews. 2013;20:353-63.

401 [30] Ling Z, Chen J, Fang X, Zhang Z, Xu T, Gao X, et al. Experimental and

402 numerical investigation of the application of phase change materials in a simulative

403 power batteries thermal management system. Applied Energy. 2014;121:104-13.

404 [31] Doyle M, Newman J, Gozdz AS, Schmutz CN, Tarascon JM. Comparison of

405 Modeling Predictions with Experimental Data from Plastic Lithium Ion Cells. Journal

406 of The Electrochemical Society. 1996;143:1890-903.

407 [32] Wang CY, Srinivasan V. Computational battery dynamics

408 (CBD) - electrochemical/thermal coupled modeling and multi-scale modeling.

409 Journal of Power Sources. 2002;110:364-76.

410 [33] Kumaresan K, Sikha G, White RE. Thermal model for a Li-ion cell. Journal 
411 of the Electrochemical Society. 2008;155:A164-A71.

412 [34] Zhang X. Thermal analysis of a cylindrical lithium-ion battery.

413 Electrochimica Acta. 2011;56:1246-55.

$414 \quad$ Figure Captions

415 Fig. 1 Schematic of experiment: (a) A 5S4P battery pack, temperature of six cells

416 (marked in green) was measured through K-type thermo-couples; (b) structure

417 of the air channel

418 Fig. 2 Illustration of the simplified model for preliminary CFD study which

419 determines the surface convective heat transfer rate (temperature of six walls of

$420 \quad$ inside box treated as constant $42{ }^{\circ} \mathrm{C}$ )

421 Fig. 3 Comparison of the maximum temperature in the battery pack between the

422 completely passive thermal management system and the hybrid system that

423 combines PCMs and forced air convection with discharge rate: (a) 1C; (b) $1.5 \mathrm{C}$;

$424 \quad$ (c) $2 \mathrm{C}$

425 Fig. 4 Comparison of historic average maximum temperature difference in passive

$426 \quad$ and hybrid systems

427 Fig. 5 History of the battery maximum temperature in the hybrid thermal 
429 Fig. 6 Comparison of historic average maximum temperature difference in the

430 hybrid system with different airspeeds (discharge rate: 1.5C).

431 Fig. 7 Comparison between numerical results and experiment in the cycling with

432 discharge rate of $1.5 \mathrm{C}$ : temperature of (a) Battery 5\# and (b) Battery 2\# in the

433 passive thermal management system; temperature of (c) Battery 5\# and Battery

$4342 \#$ in the hybrid system with airspeed of $5 \mathrm{~ms}^{-1}$

435 Fig. 8 DSC curves for RT44HC (80 wt\%)/EG composites

436 Fig. 9 History of the PCM melting fraction in the hybrid thermal management

437 systems with different airspeeds (pack discharge rate: $1.5 \mathrm{C}$ )

438 


\section{Table}

440 Table 1 Specification of Li-ion battery module

\begin{tabular}{ll}
\hline Property & Specification \\
\hline Cell type & Type 18650 \\
Module capacity & $10.4 \mathrm{Ah}$ \\
Pack operating voltage & $13.75 \mathrm{~V}-21.25 \mathrm{~V}$ \\
Max. discharge rate & 2 C-rate $(20.8 \mathrm{~A})$ \\
& \\
Max. Charge rate & $1 \mathrm{C}-$ rate $(10.4 \mathrm{~A})$ \\
\end{tabular}

441 Table 2 Thermo-physical properties of battery cell

\begin{tabular}{|c|c|}
\hline Property & Value \\
\hline Density $\left(\mathrm{kg} \mathrm{m}^{-3}\right)$ & 2700 \\
\hline Thermal conductivity ( $\mathrm{W} \mathrm{m} \mathrm{m}^{-1} \mathrm{~K}^{-1}$ ) & 7.14 \\
\hline Specific heat $\left(\mathrm{kJ} \mathrm{kg}^{-1}{ }^{\mathrm{o}} \mathrm{C}^{-1}\right)$ & 0.9 \\
\hline
\end{tabular}

442 Table 3 Thermo-physical properties of RT44HC/EG composite

\begin{tabular}{ll}
\hline Property & Value \\
\hline
\end{tabular}

EG mass fraction (\%) $20 \%$ 
Bulk density $\left(\mathrm{kg} \mathrm{m}^{-3}\right)$

Specific heat $\left(\mathrm{kJ} \mathrm{kg}^{-1}{ }^{\circ} \mathrm{C}^{-1}\right)$

Latent heat $\left(\mathrm{kJ} \mathrm{kg}^{-1}\right)$

Thermal conductivity $\left(\mathrm{W} \mathrm{m}^{-1} \mathrm{~K}^{-1}\right)$
714

181

7.85

443 Table 4 Heat transfer coefficient for each surface and the total heat transfer rate

\begin{tabular}{|c|c|c|c|c|c|}
\hline & & $5 \mathrm{~m} \mathrm{~s}^{-1}$ & $3 \mathrm{~m} \mathrm{~s}^{-1}$ & $1 \mathrm{~m} \mathrm{~s}^{-1}$ & Natural \\
\hline & & & & & convection \\
\hline Surface heat & Downwind & 28 & 19 & 13 & 9.9 \\
\hline transfer & Bottom & 34 & 16 & 11 & 8.8 \\
\hline coefficient & Upwind & 58 & 27 & 25 & 9.9 \\
\hline \multirow[t]{2}{*}{$\left(\mathrm{W} \mathrm{m} \mathrm{m}^{-2} \mathrm{~K}^{-1}\right)$} & Side & 46 & 21 & 14 & 11.6 \\
\hline & Top & 36 & 19 & 11 & 9.9 \\
\hline
\end{tabular}

444 


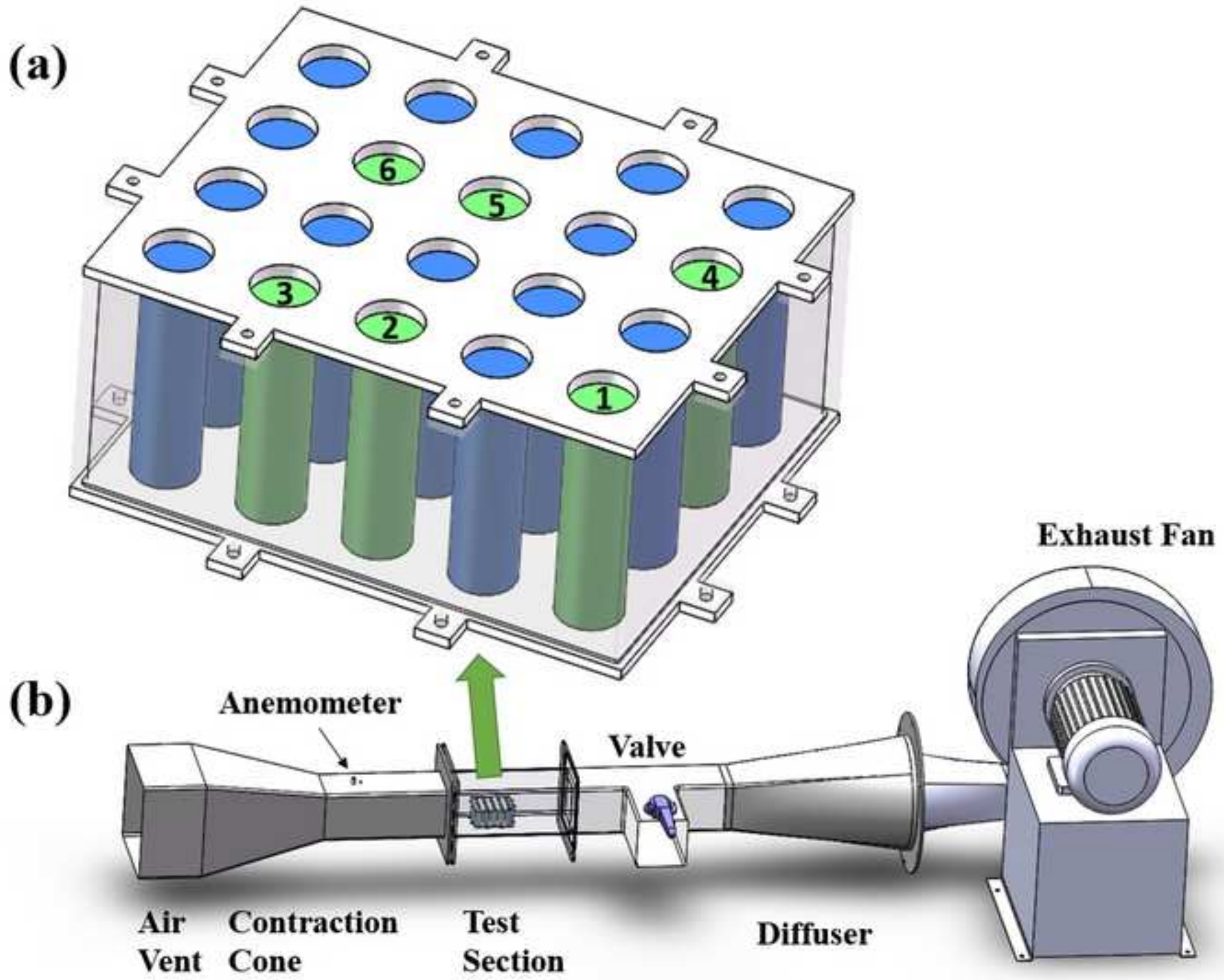




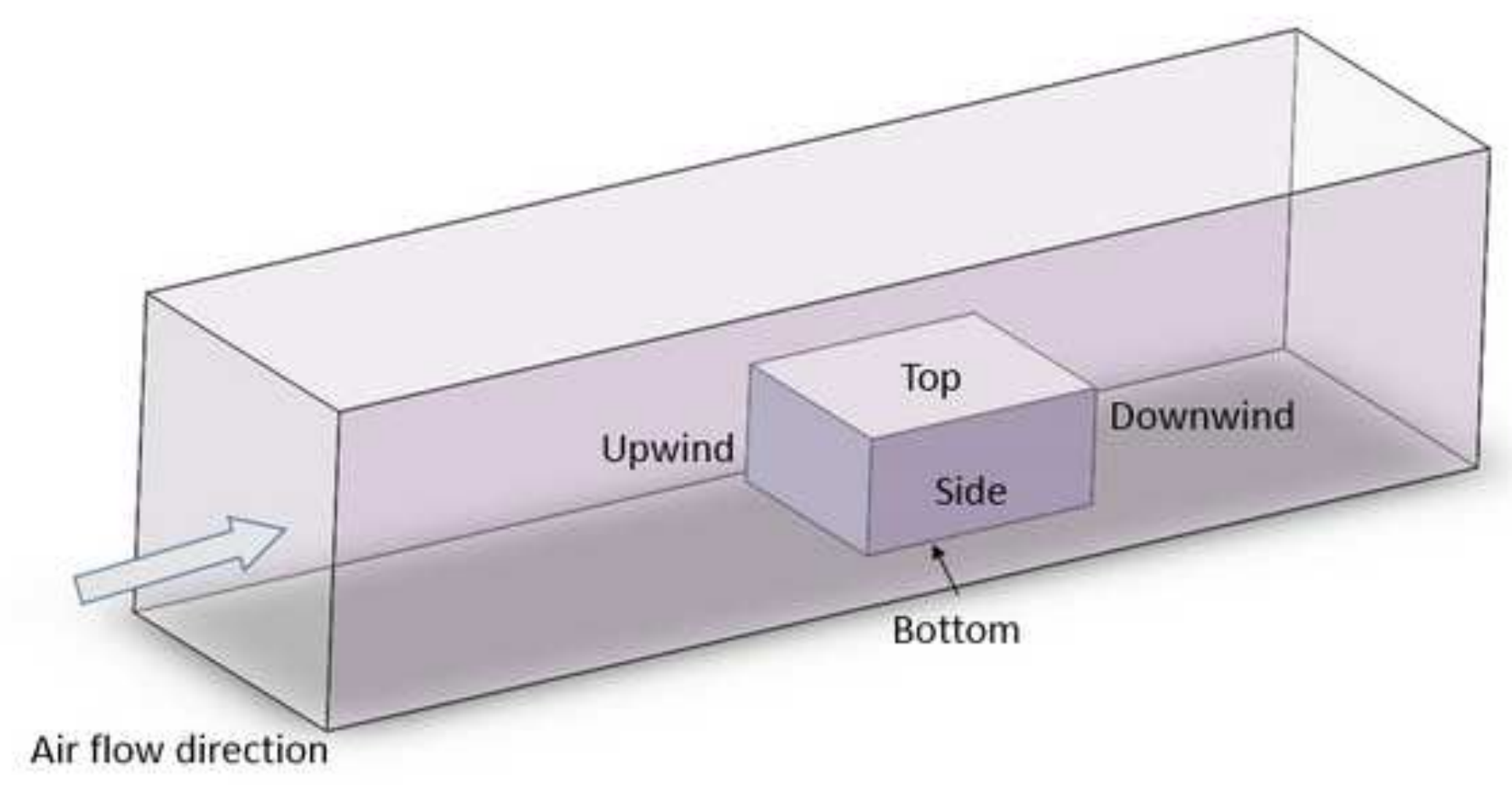

Air flow direction

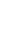




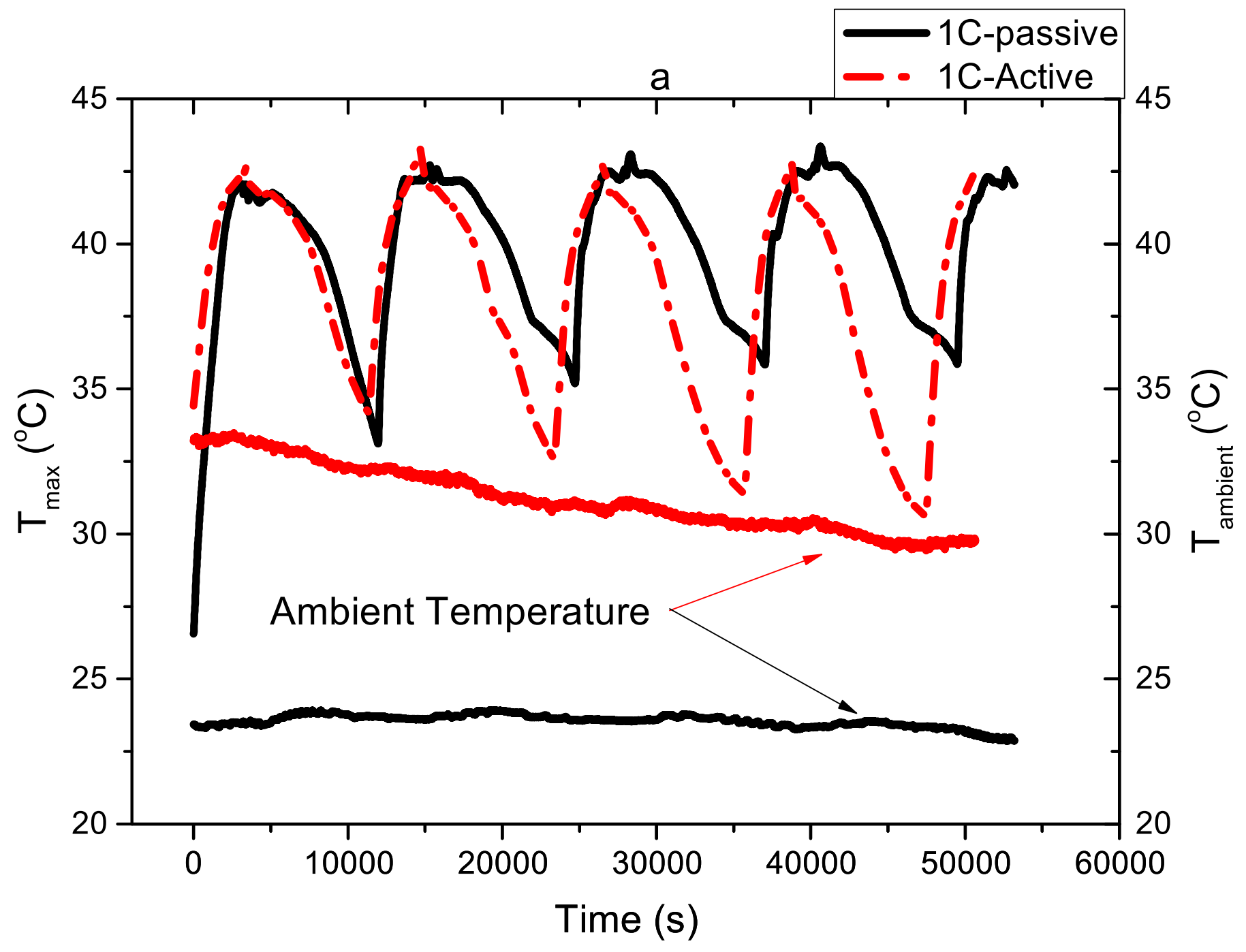




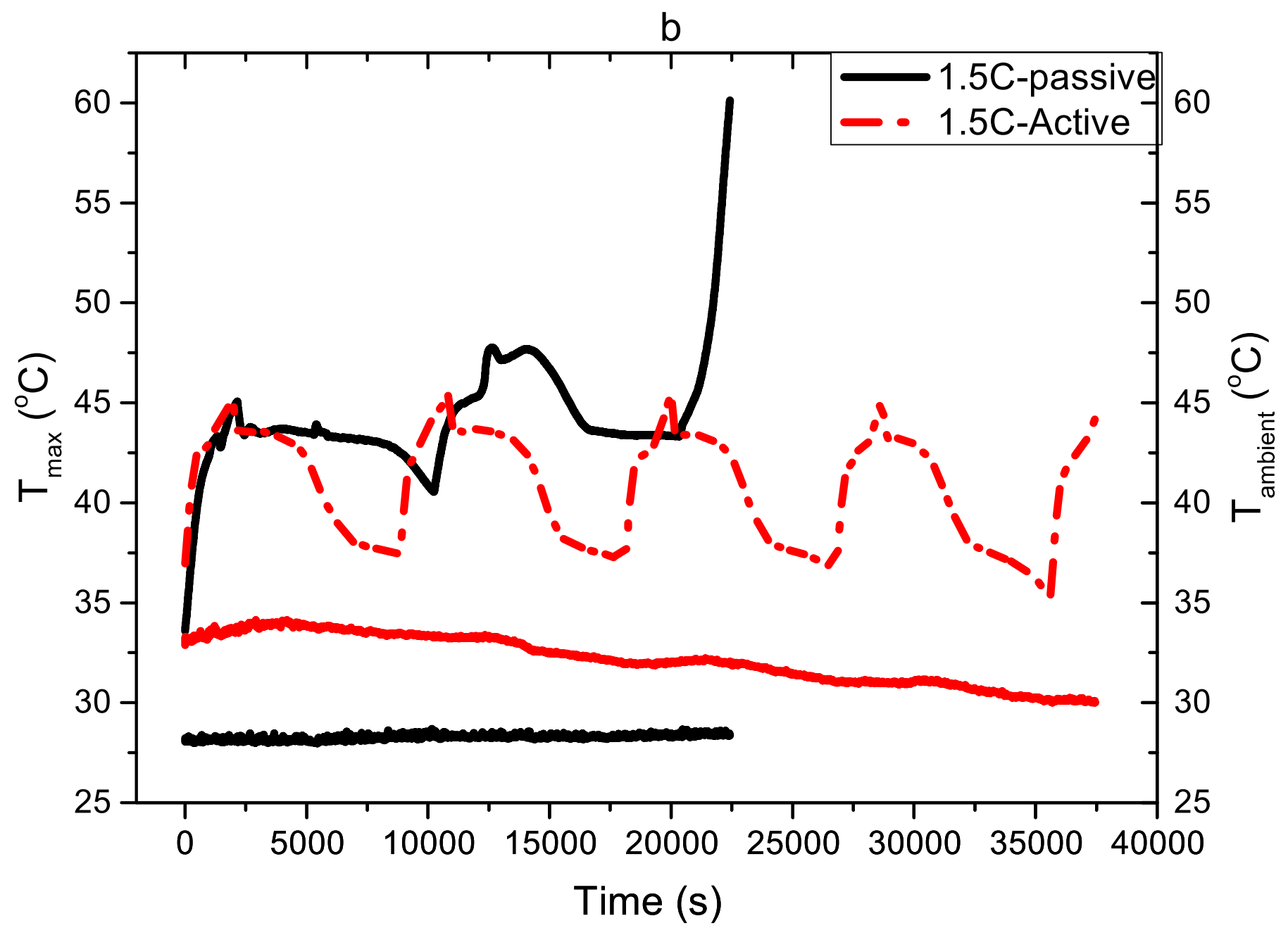




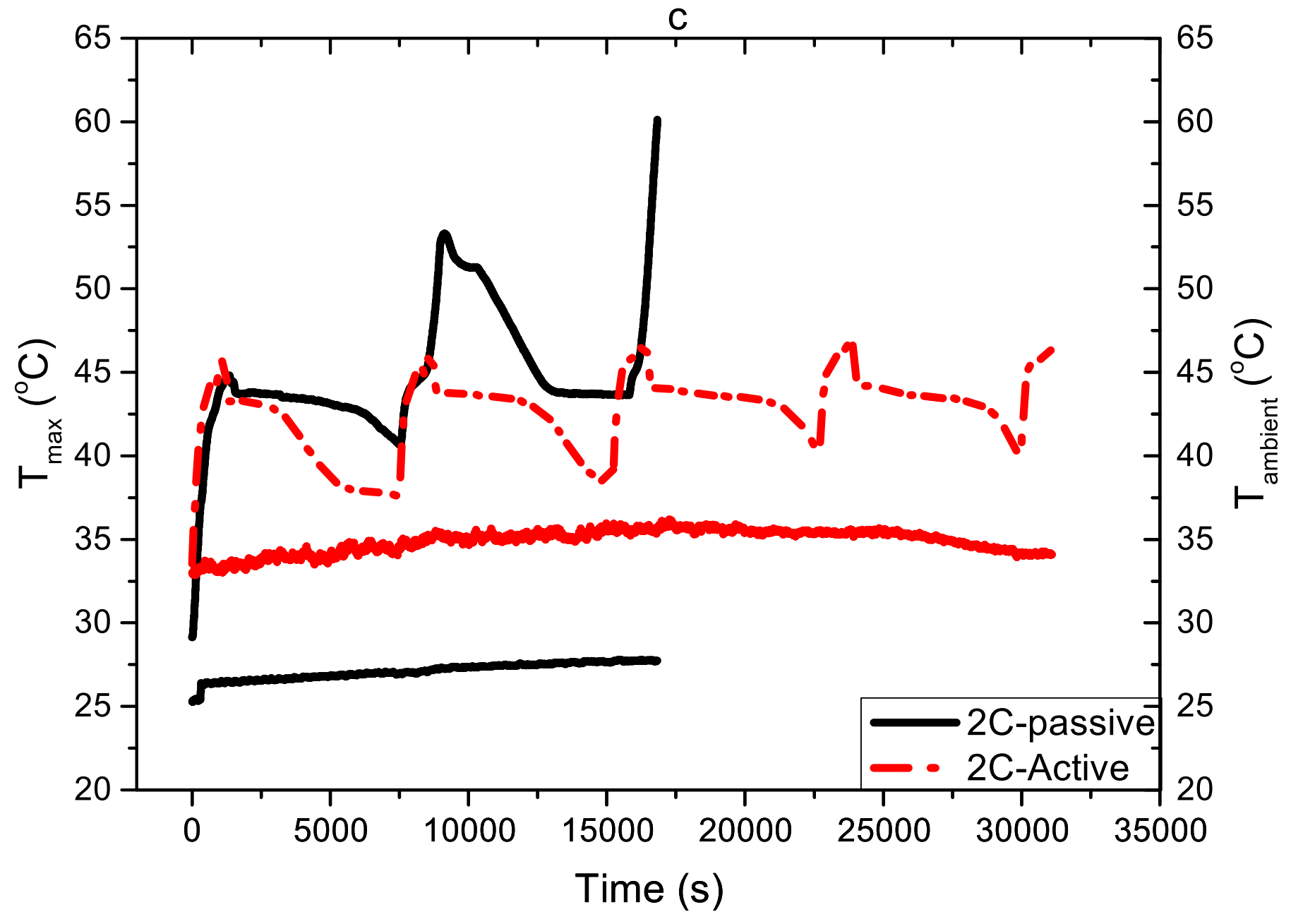


a passive, $1.5 \mathrm{C}, 2.7$

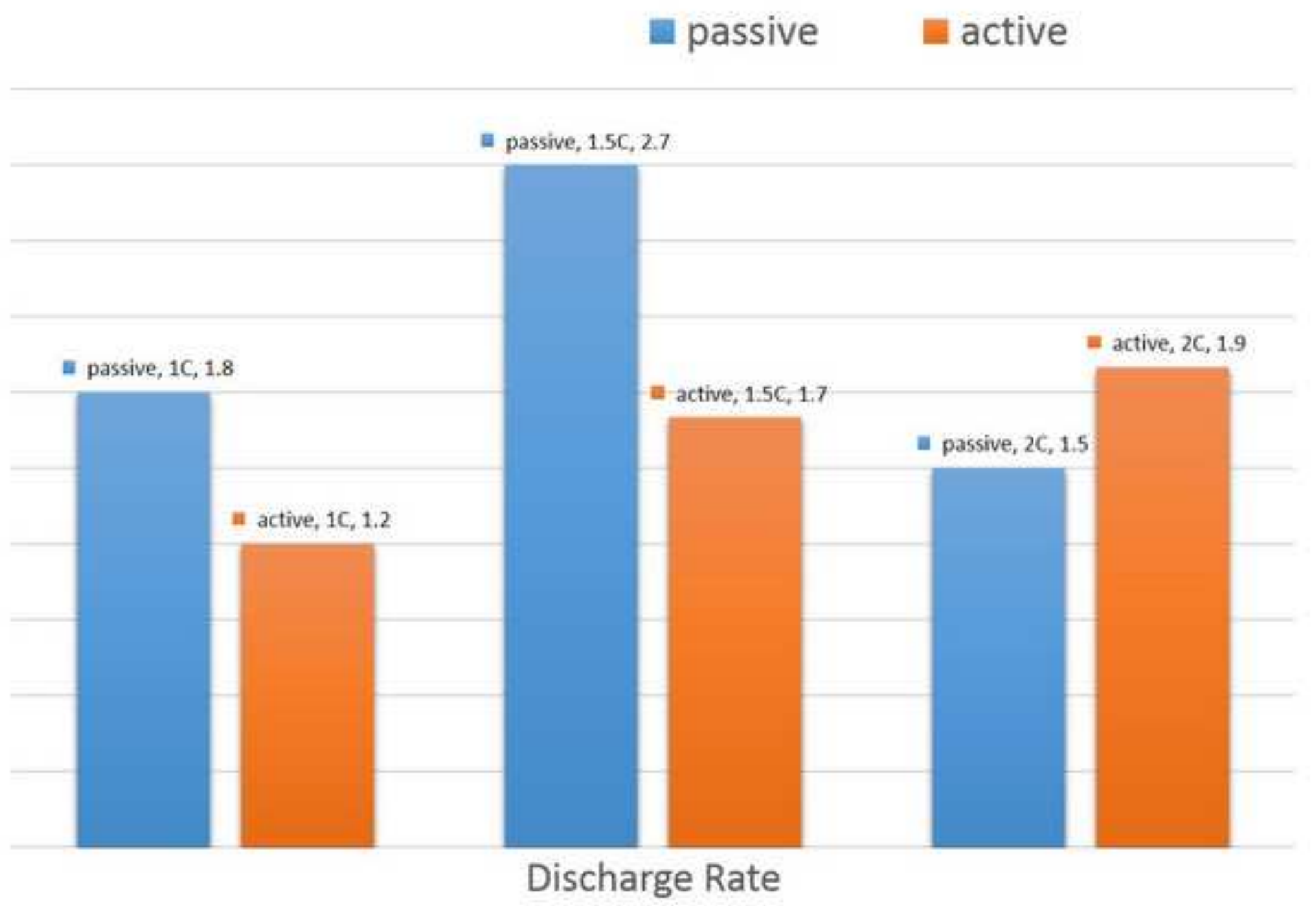

Discharge Rate

몸 active

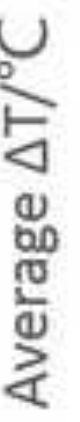

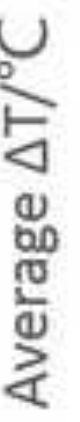

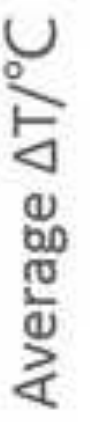

.




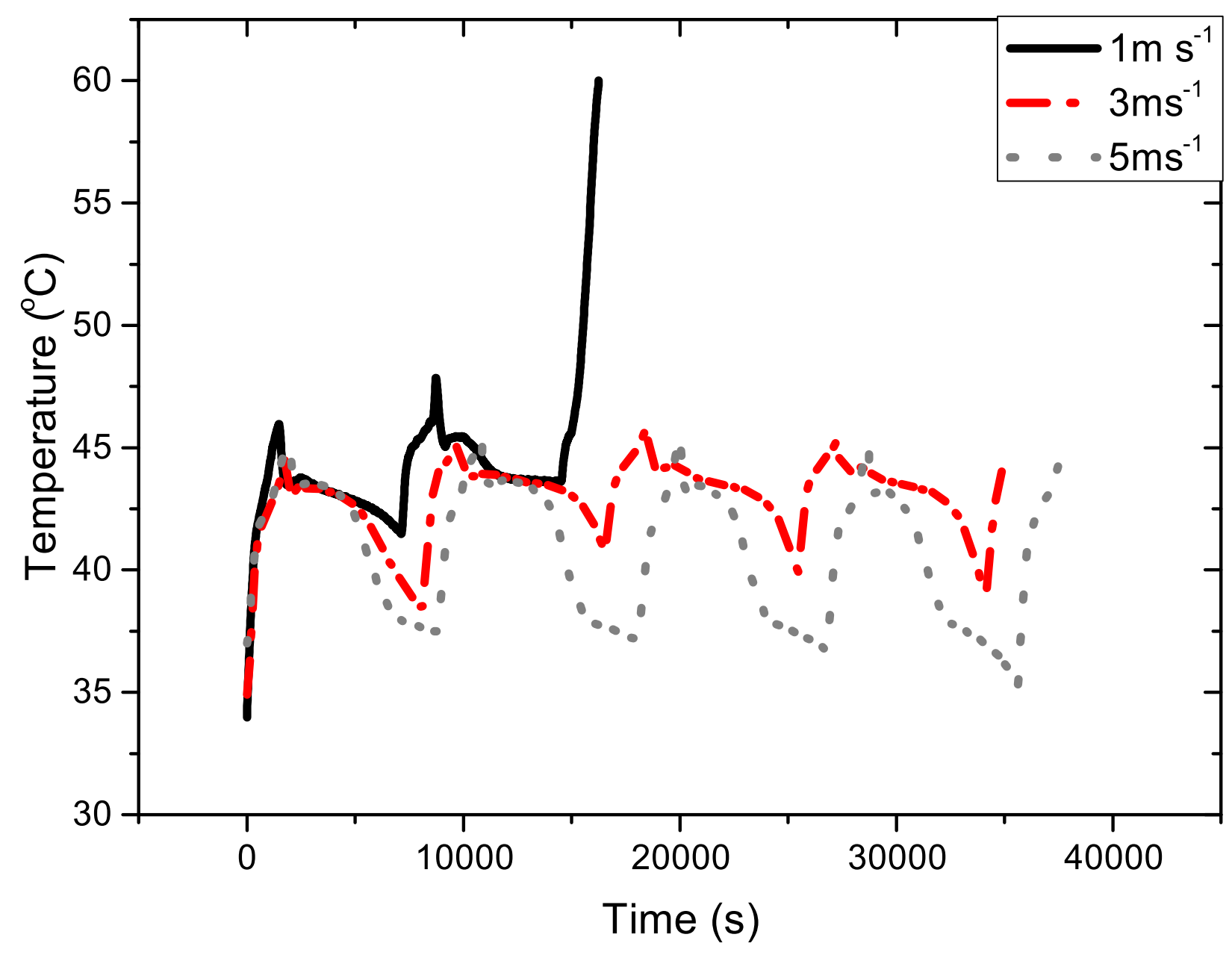




\section{Figure6}

3

๖

1

2

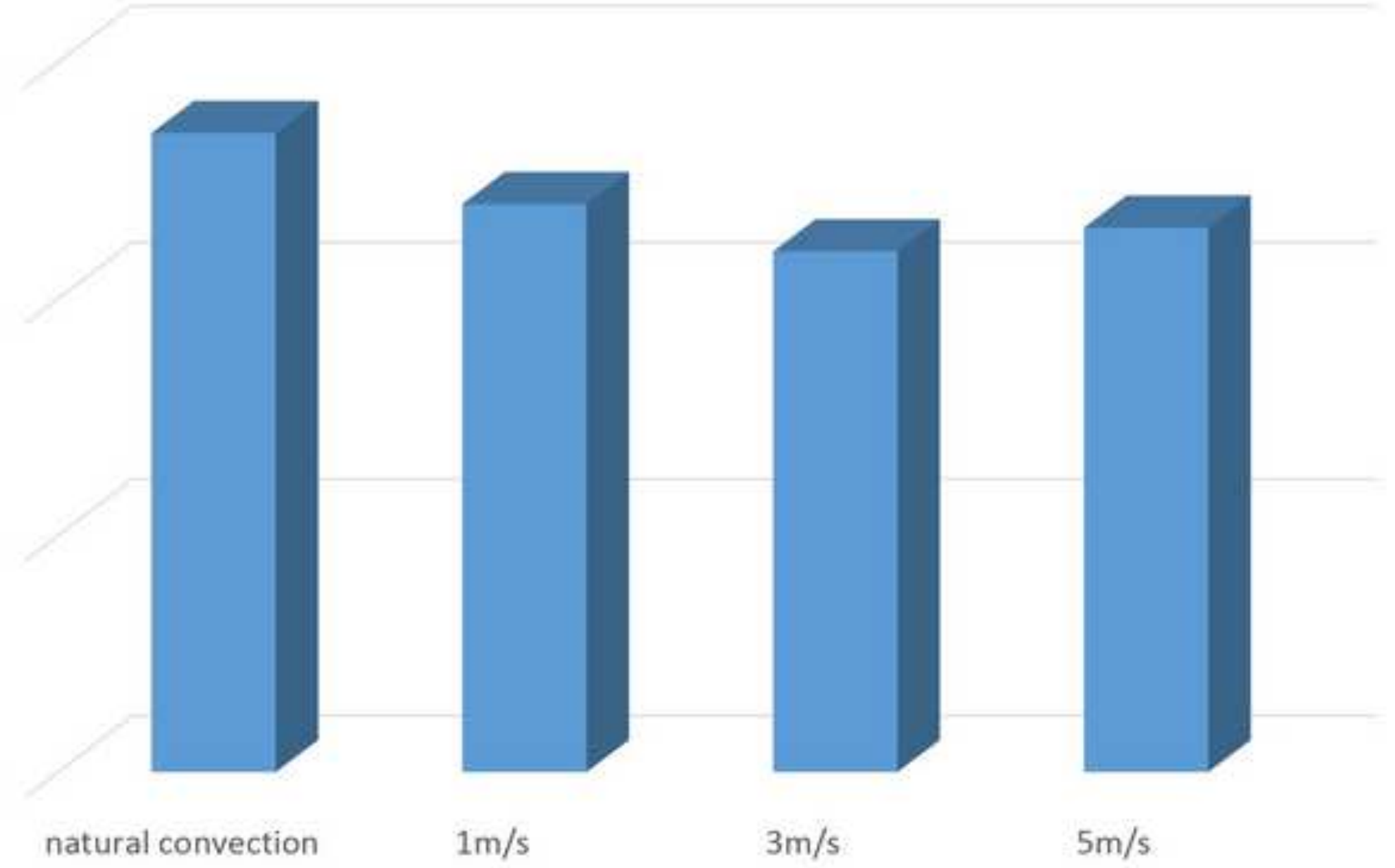




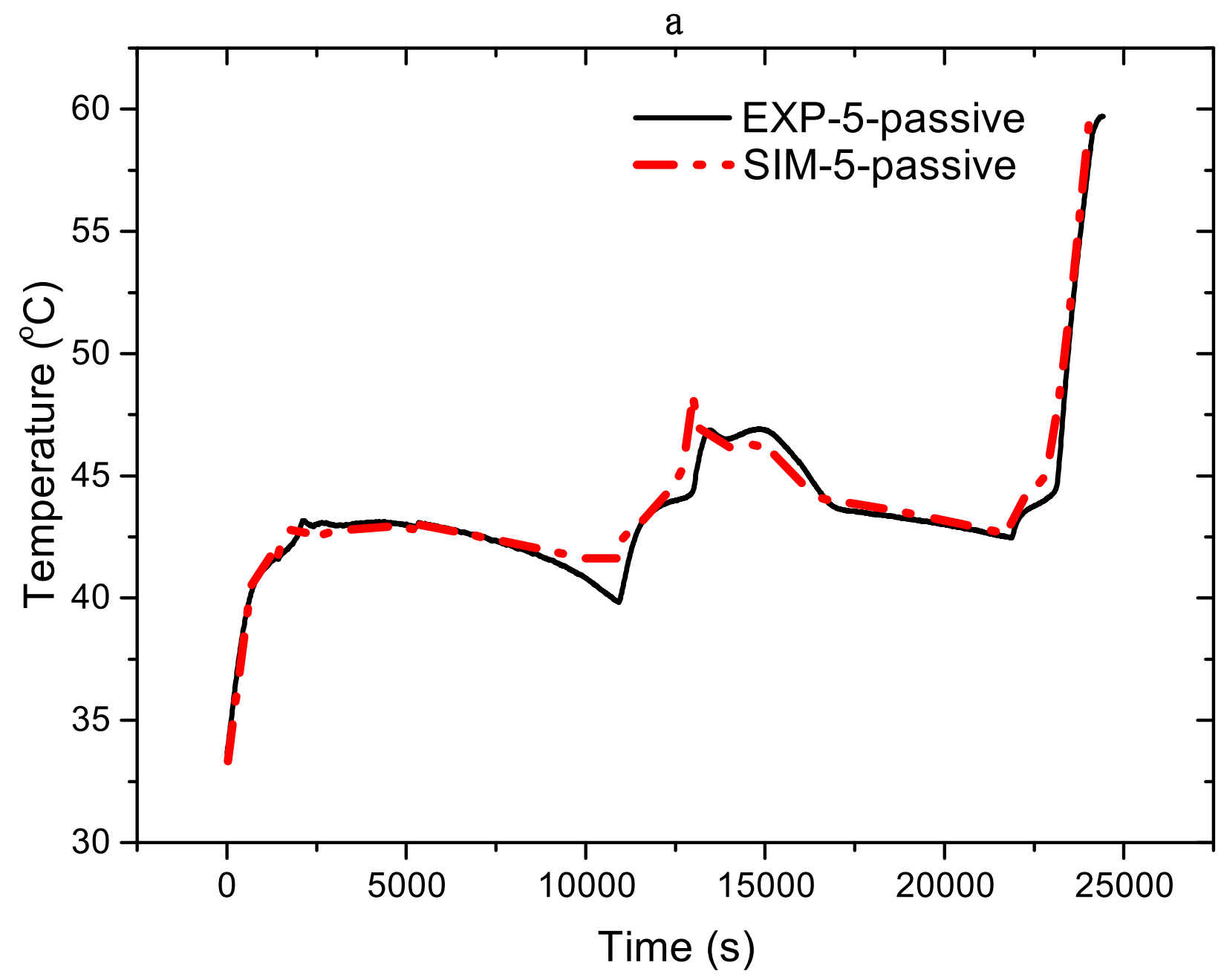




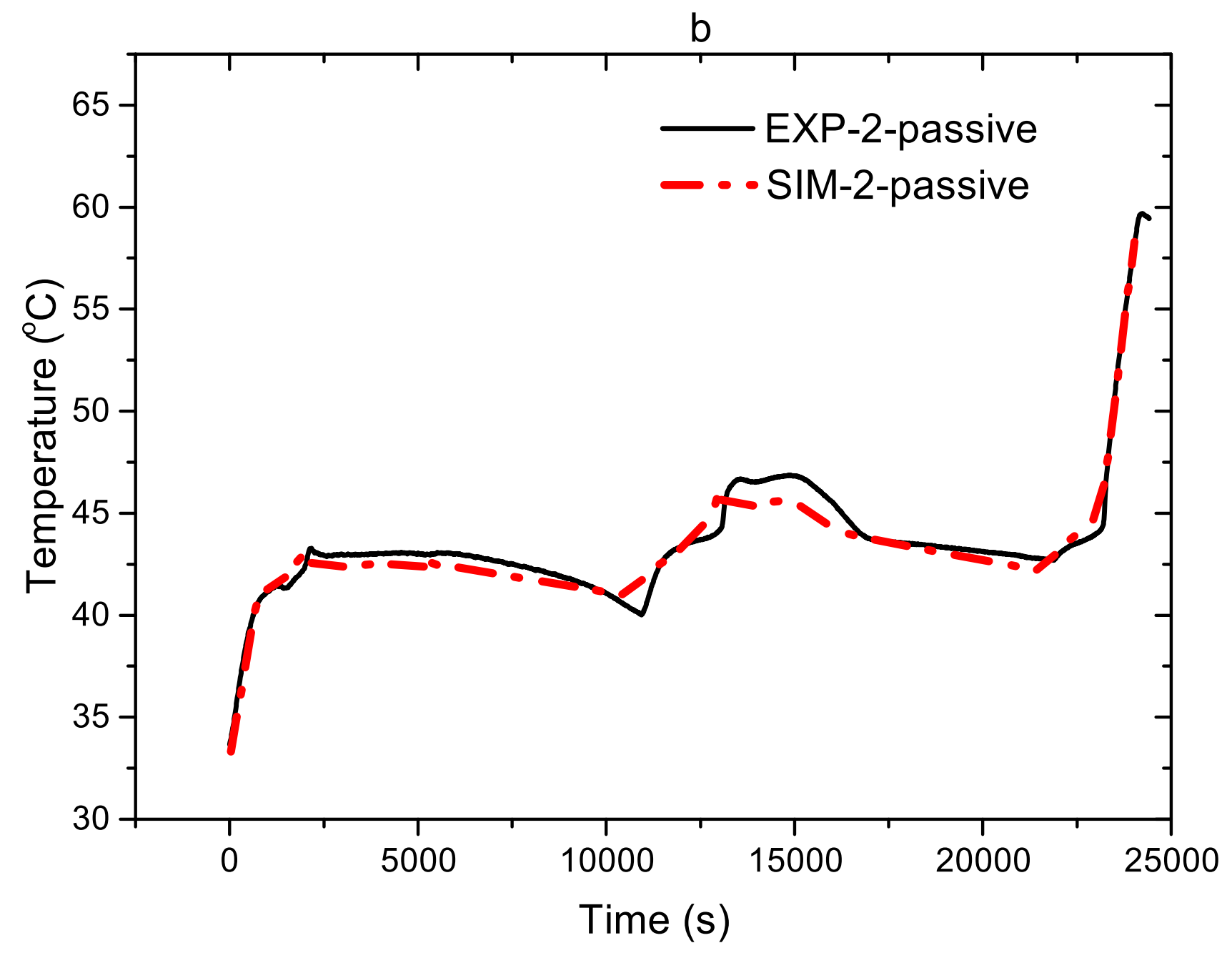

Figure7b 


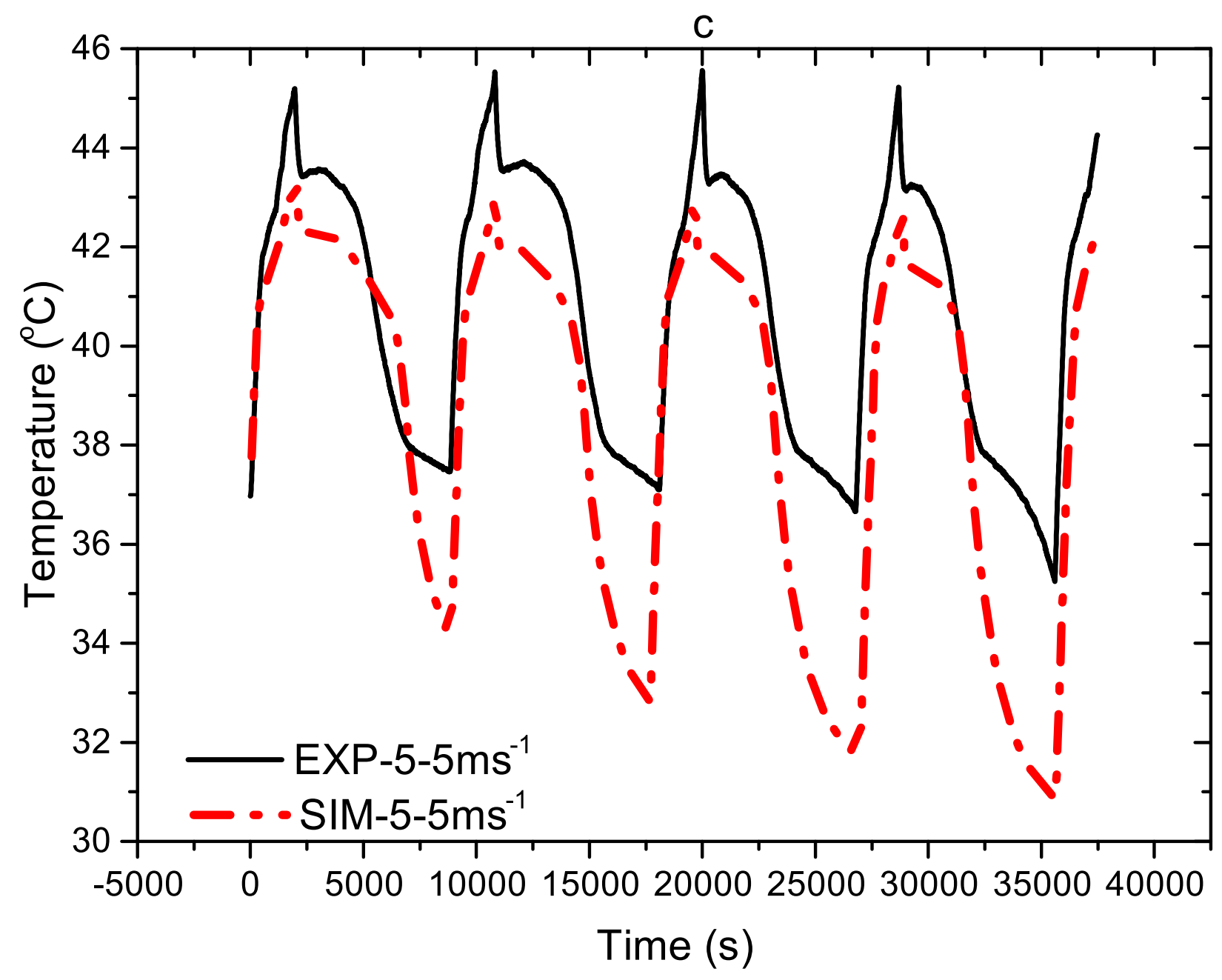




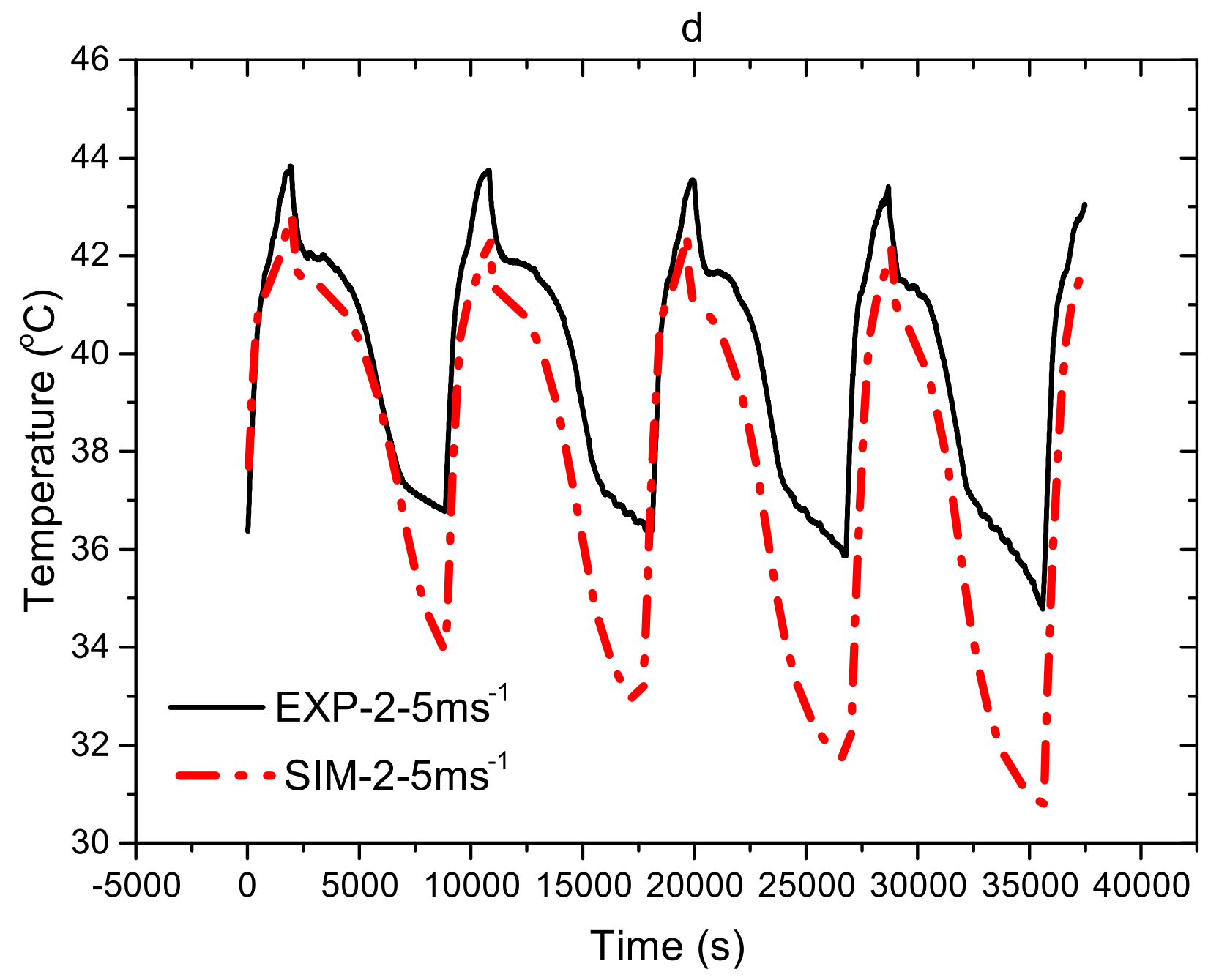




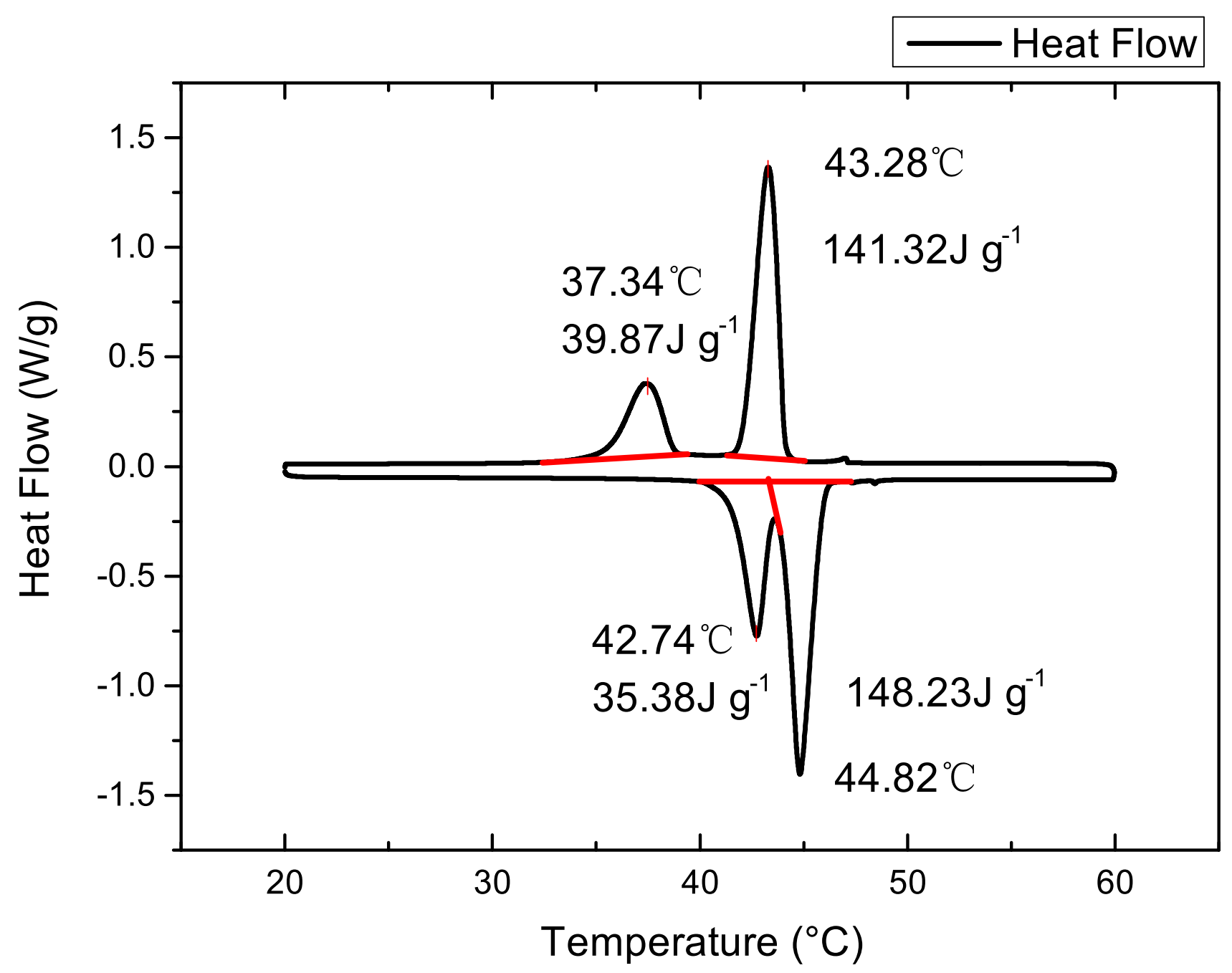


Figure 9

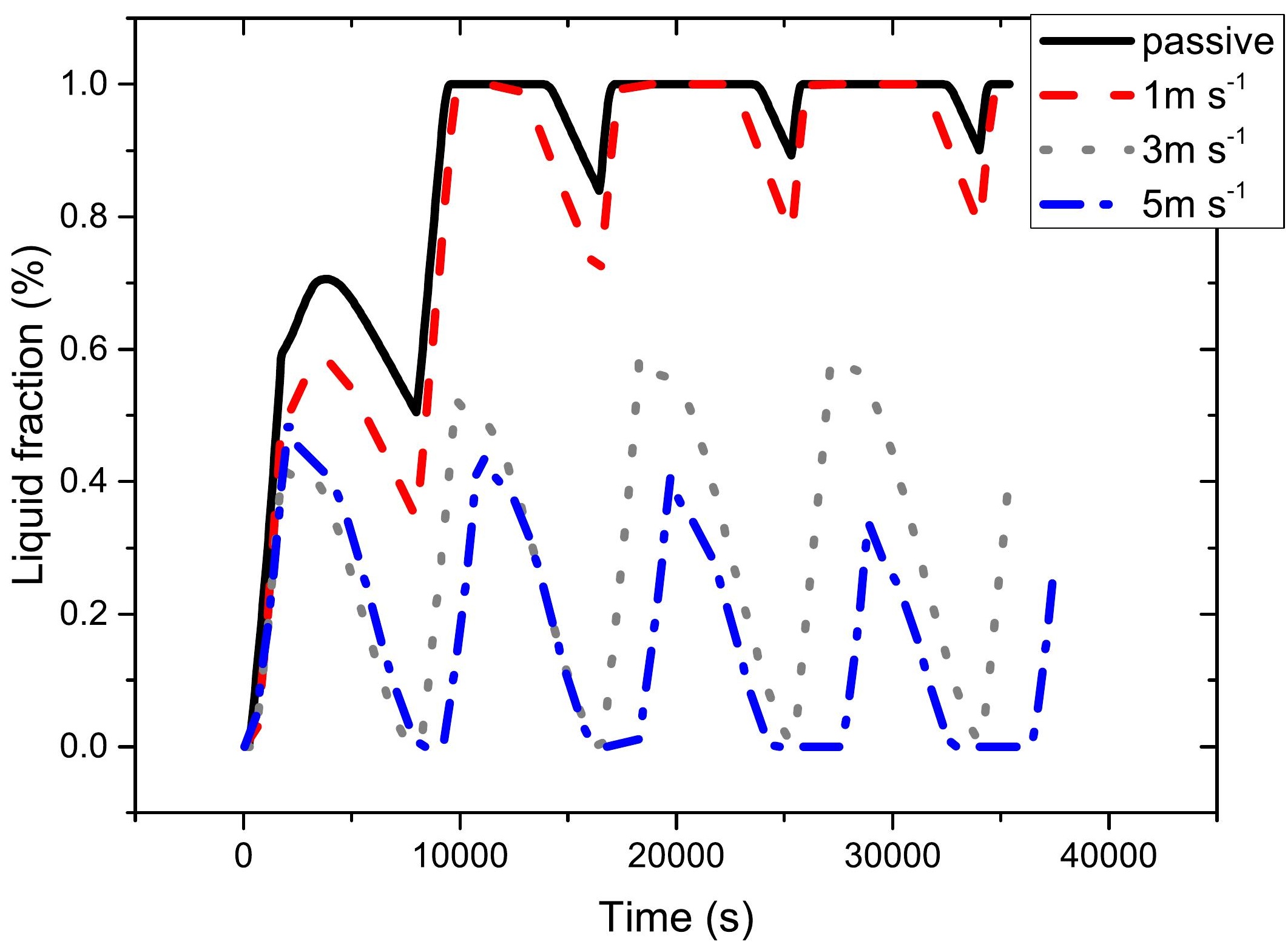

